\title{
KONTROVERSI HUKUM ROKOK DALAM KITAB IRSYĀD AL-IKHWĀN KARYA SYEKH IHSAN MUHAMMAD DAHLAN
}

\author{
R. Aris Hidayat \\ Balai penelitian dan pengembangan agama Semarang \\ E-mail:hroch_aris@yahoo.co.id
}

\begin{abstract}
Fatwa MUI on illicit nature of cigarettes, sparking a debate in the public. Polemics involving the government, tobacco companies, tobacco farmers, cigarette consumers, clergy, health organizations and other community elements. Polemic about the law of cigarettes, according to the search on the manuscript, actually has been going on long before the fatwa MUI. It can be seen on a manuscript entitled Irsyad Al-Ikhwan, work of Sheikh Ihsan Muhammad Dahlan of Boarding Schools (Pondok Pesantren) Jampes Kediri East Java. According to Sheikh Ihsan, the legal position of smoking is found only opinions / ijtihad of the scholars alone, that would be deviation (there is a difference of opinion). Smoking is not a single legal position, some have argued haram, halal, permissible, and even beneficial makruh. It happens because there is a precondition in the case of smoking.
\end{abstract}

Keywords: Cigarette; Controversy; Law; Script

\begin{abstract}
ABSTRAK
Fatwa MUI tentang sifat bahaya rokok, memicu perdebatan di masyarakat, yaitu polemik yang melibatkan pemerintah, perusahaan tembakau, petani tembakau, konsumen rokok, kyai atau tokoh agama, organisasi kesehatan dan elemen masyarakat lainnya. Polemik tentang hukum rokok, menurut hasil pencarian naskahnya, sebenarnya sudah terjadi jauh sebelum fatwa MUI dikeluarkan. Hal itu bisa dilihat pada manuskrip yang berjudul Irsyad Al-Ikhwan, karya Sheikh Ihsan Muhammad Dahlan dari Pondok
\end{abstract}


Pesantren Jampes Kediri Jawa Timur. Menurut Sheikh Ihsan, posisi hukum merokok hanya merupakan opini / ijtihad para ulama saja, sehingga menimbulkan perbedaan pendapat. Posisi hukum merokok tidaklah tunggal, ada yang berpendapat haram, halal, diperbolehkan, dan bahkan makruh. Itu terjadi karena ada prasyarat dalam kasus merokok.

Kata kunci: Hukum; Naskah; Kontroversi; Rokok

\section{A. Pendahuluan}

Intelektual muslim nusantara masa lampau banyak meninggalkan naskah-naskah keagamaan yang sangat penting. Naskah-naskah keagamaan tersebut merupakan khazanah intelektual dan warisan budaya bangsa yang sangat berharga. Hasil-hasil karya intelektual yang merupakan bagian dari usaha ijtihād (al-Khudhari, 1981: 114; Abū Zahrah, t.t.,: 301) dan pengembangan kajian keislaman tersebut tidak akan memiliki makna dan nilai bagi kehidupan masyarakat muslim saat ini dan masa mendatang apabila tidak dipelihara, diteliti, dikaji dan disebarluaskan di tengahtengah masyarakat.

Kitab-kitab yang ditemukan di Nusantara, baik kitab klasik maupun kitab modern bila dilihat dari jenis keilmuannya sangat beragam. Ilmu keislaman yang berkembang di Nusantara, di antaranya: akidah atau ushuluddin, figh dengan aneka macam cabangnya, akhlak, tasawuf, qawa' id al- lughah (nahwu, sharaf, balaghah), tafsir, ilmu tafsir, hadits dan mushthalah al-hadits. Di antara cabang-cabang ilmu keislaman, fiqih menduduki peranan yang sangat penting karena fiqih mengandung berbagai implikasi konkret bagi perilaku keseharian individu masyarakat. Fiqihlah yang menjelaskan kepada kaum muslimin hal-hal yang wajib dilakukan, yang disunatkan, yang dilarang dan lain sebagainya sehingga di pesantren, fiqih merupakan disiplin ilmu yang sangat diminati. Hampir tidak ada satu pesantren pun yang tidak mengajarkan fiqih.

Kitab-kitab klasik, termasuk kitab-kitab tentang fiqih yang merupakan penopang utama tradisi keilmuan Islam di Indonesia, ditulis pada sekitar abad ke-10 sampai abad ke-15 (Bruinessen, 1995: 30). Penelitian yang dilakukan oleh Martin van Bruinessen menyimpulkan bahwa hampir semua kitab fiqih yang diajarkan di Nusantara (Indonesia) adalah kitab-kitab fiqih yang bermadzhab Syafi'i baik yang berupa matan, syarh (komentar) maupun 
hasyiyah (catatan). Dari sekian banyak kitab fiqih yang bermadzhab Syafi'i itu, Bruinessen mengelompokkannya menjadi tiga "keluarga” yang menonjol, yaitu:

1. "Keluarga" dari kitab Muharrar oleh ar-Rafi'i yang kemudian disingkat oleh An-Nawawi menjadi Minhājuṭ Taalibìn. Kitab ini melahirkan banyak syarah, di antaranya: Mughnīl Muhtāj ilā Ma'rifati Ma'āni Alfāzhil Minhāj oleh Syamsuddin Muhammad bin Muhammad al-Khathīb asy-Syarbīnī (w. 977 H.), Tuhfatul Muḥtāj bi Syarḥ al-Minhāj oleh Syihabuddin Aḥmad bin Hajar al-Haitami (w. 973 H.), Nihāyatul Muḥtāj ilā Syarḥil Minhāj oleh Syamsuddīn Muhammad bin Abu al-'Abbas Ahmad bin Hamzah bin Syihabuddīn ar-Ramlī (w. 1004 H.) dan Kanz ar-Rāghibin oleh Jalaluddin al-Mahalli (w. 864) yang kemudian diberi hasyiyah oleh al-Qalyubi dan 'Umairah. Kitab Minhājuṭ Tạlibìn juga diringkas oleh Zakariya al-Anshari (w. 925 H.) dengan nama Manhajut Tulläb (yang kemudian disyarahi sendiri oleh penulisnya dengan judul Fathul Wahhāb bi Syarḥ Manhajiṭ Tulläb).

2. "Keluarga" dari kitab at-Taqrïb yang juga dikenal dengan Mukhtashar oleh Abu Syuja ' al-Ishfahani (w. 593 H.). Kitab-kitab yang termasuk di dalamnya adalah: syarah at-Taqrïb yang diberi nama Fathul Qarīb oleh Ibn Qasim al-Ghazi (w. 918) dan kemudian diberi hasyiyah oleh al-Bajuri (w. 1277), Kifäyatul Akhyār oleh adDimasyqi (w. 829), Iqnā’ oleh asy-Syarbini (w. 977), Taqrīr oleh 'Awwad dan Tuhfatul Habīb oleh al-Bujairimi (w. 1100).

3. "Keluarga” dari kitab Qurratul 'Ain oleh al-Malibari (w. 975) yang kemudian disyarahi sendiri dengan judul Fathul $M u$ 'in bi Syarhi Qurratil 'Ain yang kemudian diberi hasyiyah oleh Nawawi al-Bantani (w. 1315) dengan judul Nihāyatuz Zain fi Irsyādil Mubtadi'̄n bi Syarhi Fathil Mu'in, oleh Sayyid Bakri Syatha (w. 1300) dengan judul I'ānatuṭ Tạlibìn dan oleh Alwi as-Sagaf (w. 1300) dengan judul Tarsyih al-Mustafidin (Aliman, 2010: ix).

Di samping ketiga "keluarga" tersebut, Van den Berg menyebut satu "keluarga" kitab fiqh lagi yaitu Minhāj al-Qawìm oleh Ibnu Ḥajar alHaitami (pengarang Tuhfat al-Muhtāj) yang merupakan syarah dari alMuqaddimat al-Hadramiyah oleh Abdullah bin Abdul Karim Bafadhal. Kitab 
al-Muqaddimat al-Ḥadramiyah disyarahi oleh Sulaiman al-Kurdi (w. 1194) dengan nama al-Hawāsy al-Madaniyah (Aliman:118-121). Di Jawa, kitabkitab klasik termasuk kitab-kitab fikih yang diajarkan di berbagai pesantren oleh para ulama, umumnya bersumber dari kitab-kitab tersebut.

Keberadaan ulama di Jawa mempunyai peran penting dalam dinamika kehidupan dan pemikiran di Indonesia. Dalam bidang pemikiran, ulama-ulama itu telah banyak memproduksi karya tulis yang sangat berharga dan masih terus digunakan oleh masyarakat hingga saat ini. Para ulama yang cukup produktif menghasilkan karya di antaranya Kyai Hasyim Asy'ari dari Jombang, Kyai Muhammad Shalih atau Saleh Darat dari Semarang, Kyai Mahfudz bin Abdullah dari Tremas, Pacitan, dan Syekh Ihsan dari Jampes Kediri. Selain itu, masih banyak ulama lain yang aktif menulis, menerjemahkan, atau menulis ulang karya ulama terdahulu.

Kyai Hasyim Asy’ari, seorang ulama asal Jombang Jawa Timur, pendiri dan sekaligus pemimpin pertama organisasi Nahdlatul Ulama, telah menulis banyak kitab dalam berbagai bidang ilmu seperti tasawuf, fiqih dan hadis. Di antaranya adalah At-Tibyan fi an-Nahi'an Muqatha'at al-Arham wa al-Aqarib wa al-Akhawan (Penjelasan Mengenai Larangan memutuskan hubungan kerabat dan persahabatan), Adab al-Alim wa alMuta'allim (Akhlak guru dan Murid), dan al-Qalaid fi Bayan ma Yajib min al-Aqaid (Syair-syair menjelaskan kewajiban-kewajiban aqidah).

Saleh Darat dari Semarang menulis kitab fiqih dalam bahasa Jawa Majmu'ah Al-Syariah Al-Kafiyah li al-Awam, juga menulis karya singkat mengenai kesucian beribadah yang masih tetap ada berjudul Latha'if AlThaharah. Ia juga menerjemahkan dan memberi penjelasan atas kitab Jawhara al-Tauhid. Kitab tersebut diberi judul Sabil al-abid 'ala Jawhara al-Tauhìd. Kyai Mahfudz bin Abdullah dari Tremas Pacitan Jawa Timur menulis sebuah syarah Al-Muqaddimah Al-Haramiyah oleh Abdullah Ba-Fadhl.

Selain nama-nama yang telah disebutkan di atas, masih banyak ulama-ulama yang telah menulis karya keagamaan baik berupa karya asli, terjemahan, syarah (komentar), hasyiyah (komentar atas syarah), nadzam atas karya terdahulu dan lainnya. 
Pada penelitian ini menarik untuk dikaji salah satu karya seorang ulama bernama Kyai Ihsan dari Pondok Pesantren Jampes Kediri, Jawa Timur. Ia menulis berbagai kitab, di antaranya kitab Tasrih al-Ibarat pada tahun 1932 M dan kitab Manahij al-Imdad pada tahun 1940 M. Kitab Tasrih al-Ibarat merupakan syarah/penjabaran atas kitab Natijat al-Miqat karya KH. Dahlan dari Semarang. Kitab Manahij al-Imdad merupakan syarah (komentar) atas kitab Irsyad al-Ibad ila Sabili Rasyad karya Syaikh Zainuddin bin Abdul Aziz Al-Malibari (w.982 H). Karya-karyanya yang lain di antaranya kitab Shiraj at-Thalibin (Lentera Hati) yang diterbitkan oleh penerbit Musthafa Baby Al Halaby Cairo Mesir, dan kitab Irsyād al-Ikhwān li bayāni syurb al-Qahwah wa al-Dukhān. Kitab yang disebut terakhir ini merupakan syarah dari kitab Tadzkirat al-Ikhwan karya $\mathrm{KH}$. Dahlan dari Semarang. Kitab inilah yang akan diteliti pada penelitian ini.

Salah satu karya Syekh Ihsan Muhammad Dahlan berjudul Irsyad al-Ikhwan atau lengkapnya Irsyād al-Ikhwān li bayāni syurb al-Qahwah wa al-Dukhān. Kitab ini secara umum membicarakan tentang hukum merokok dan meminum kopi. Kitab inilah yang akan dikaji pada penelitian ini, namun kajian difokuskan pada permasalahan rokok, sedangkan permasalahan kopi akan dikaji secara khusus pada kesempatan lain.

Topik tentang hukum merokok menarik untuk diangkat dalam penelitian ini karena dua alasan pokok. Pertama, polemik atau kontroversi tentang hukum merokok masih berlangsung sampai sekarang, bahkan diduga masih akan terus berlangsung di masa mendatang. Topik ini semakin menarik untuk dibahas ketika dikaitkan dengan adanya fatwa MUI tentang haram merokok. Kedua, topik ini menarik dilihat dari berbagai aspek, baik aspek agama, sosial, ekonomi, budaya, dan lainnya. Selain itu, topik ini menarik karena ditulis oleh seorang ulama lokal namun mengambil referensi dari ulama-ulama Timur Tengah.

Fatwa MUI pusat tentang haramnya rokok, memicu adanya kontroversi pada pemerintah, pengusaha rokok, petani tembakau, konsumen rokok, ulama, organisasi kesehatan dan seluruh elemen masyarakat lainnya. Kesadaran akan pluralitas di negeri ini, telah memicu terjadinya ketegangan dalam masyarakat berkenaan dengan kontroversi tentang fatwa MUI. Dalam konteks ini, penting kiranya hasil penelitian ini dijadikan sebagai salah satu referensi untuk menjawab persoalan fatwa MUI 
tentang haram rokok yang menyebabkan kontroversi di masyarakat, ketika masyarakat masih bingung menentukan status hukum dari fatwa itu.

Mengacu pada pemaparan diatas, maka rumusan masalah penelitian adalah bagaimana pemikiran Syekh Ihsan Muhammad Dahlan dari Jampes Kediri tentang hukum rokok. Penelitian ini bertujuan untuk mengetahui pemikiran Syekh Ihsan Muhammad Dahlan tentang hukum rokok. Sasaran penelitian ini kitab Irsyād al-Ikhwān li bayāni syurb alQahwah wa al-Dukhān. Metode penelitian ini content analysis (analisis isi). Langkah-langkah analisis meliputi identifikasi karakteristik fisik kitab, dan identifikasi karakteristik isi kitab. Identifikasi karakteristik isi kitab mencakup pokok-pokok pemikiran Syekh Ihsan dalam kitab Irsyad al-Ikhwan li bayani syurb al-qahwah wa al-dukhan, khususnya tentang hukum rokok.

\section{B. Pembahasan}

\section{Biografi Syekh Ihsan Muhammad Dahlan}

Syekh Ihsan ketika masih kecil bernama Bakri. Ia lahir pada tahun 1901 Masehi. Ia adalah putra dari pasangan KH. Dahlan dan Artimah.Ayah Bakri, KH. Dahlan adalah pendiri Pondok Pesantren Jampes, Kediri. Bakri memiliki tiga saudara, dua laki-laki dan satu perempuan. Saudara laki-laki Bakri bernama Dasuki dan Marzuqi. Adapun saudara perempuan Bakri tidak diketahui namanya karena telah meninggal ketika masih kecil.

Ketika ia masih berusia 6 tahun kedua orang tuanya bercerai. KH. Dahlan tetap tinggal di Jampes, Kediri, sedangkan Artimah (ibunya) pulang ke rumah orang tuanya di Banjarmelati, Kediri. Setelah perceraian itu, Bakri dan Dasuki tinggal bersama ayahnya, KH. Dahlan, sedangkan Marzuqi ikut ibunya di Banjarmelati, Kediri. Bakri dan Dasuki diasuh oleh neneknya, Ny. Istianah di Jampes. KH. Dahlan kemudian menikah lagi dengan gadis dari Pare, Kediri, bernama Maryam. Pernikahan KH. Dahlan yang kedua ini dikaruniai sembilan orang anak, bernama Khozin, Ruqayah, Tubaji, Maslamah, Halwiyah, Muhsin, Muslim, Aminah, dan anak perempuan yang meninggal ketika dilahirkan. Bakri mendapatkan pendidikan keagamaan dari keluarganya sendiri, terutama dari neneknya (Nyai Istianah). Ia memiliki kecerdasan pikiran dan daya ingat yang cukup kuat. Ia juga tekun membaca buku, baik yang berupa kitab-kitab 
agama maupun bidang lain. Ia memiliki kesukaan menonton wayang. Di mana pun pertunjukan wayang digelar, Bakri sering mendatanginya. Ia tak peduli apakah dalangnya sudah mahir atau pemula. Karena kecerdasan dan penalarannya yang kuat, ia menjadi paham berbagai karakter dan cerita pewayangan. Bahkan, konon ia pernah menegur dan berdebat dengan seorang dalang ketika pertunjukan wayangnya dianggap melenceng dari pakem (pedoman yang sudah baku).

Kebiasan Bakri yang suka berjudi membuat risau keluarga. Kebiasaan itu merupakan larangan agama dan sangat memalukan keluarga. Neneknya, Ny. Isti’anah, merasa sangat prihatin dengan tingkah laku Bakri. Suatu hari ia mengajak Bakri berziarah ke makam leluhurnya, khususnya ke makam kakek Ny. Istianah bernama K. Yahuda di Desa Nogosari, Lorog Pacitan. Ia ditemani KH. Dahlan dan KH. Khozin. Di makam K. Yahuda inilah Ny. Isti'anah mencurahkan segala rasa khawatir dan keprihatinannya atas kebandelan cucunya itu.

Di makam itu Ny. Istianah memohon kepada Tuhan melalui K. Yahuda agar perilaku cucunya bisa berubah. Ia menyerahkan cucunya kepada Tuhan karena perilaku cucunya dianggap sudah keterlaluan. Doa yang diucapkan Ny. Istianah sebagai berikut:

"Wahai Mbah Yahuda, kami datang kepadamu dengan membawa cucumu yang bernama Bakri untuk kami serahkan kepada Tuhan melalui engkau, Bakri ini sudah keterlaluan sekali kenakalannya dan keluarga merasa dibuat malu oleh perbuatannya. Apabila Bakri ini tidak dapat berhenti atau menghentikan segala kenakalannya, maka kami minta kepada Allah untuk segera mengambilnya dan jangan diberi umur panjang".

Demikian doa yang disampaikan Ny. Istianah di makam K. Yahuda. Konon, beberapa hari setelah itu, Bakri bermimpi didatangi oleh $\mathrm{K}$. Yahuda. Dalam mimpinya, K. Yahuda meminta Bakri untuk menghentikan kebiasaan berjudi. Di dalam mimpi itu Bakri ternyata tetap tidak mau menuruti perintah K. Yahuda. Akhirnya, K. Yahuda pun bersikap tegas. Ia mengambil batu besar dan memukulkannya ke kepala Bakri hingga hancur berantakan. Mimpi inilah yang kemudian menyentak kesadaran Bakri. Sejak saat itu ia lebih sering menyendiri, merenungkan makna mimpinya itu. 
Ia mulai berfikir tentang makna keberadaannya di dunia fana ini. Setelah itu, untuk pertama kali dalam hidupnya, ia keluar dari pesantren ayahnya untuk melanglang buana mencari ilmu dari satu pesantren ke pesantren lain. Waktu itu ia berusia sekitar 17 tahun. Beberapa pesantren yang sempat disinggahi Bakri di antaranya: 1) Pesantren Bendo Pare Kediri asuhan KH. Khozin (paman Bakri sendiri), 2) Pondok Pesantren Jamsaren Solo, 3) Pondok Pesantren asuhan KH. Dahlan Semarang, 4) Pondok Pesantren Mangkang Semarang, 5) Pondok Pesantren Punduh Magelang, 6) Pondok Pesantren Gondanglegi Nganjuk, 7) Pondok Pesantren Bangkalan Madura asuhan KH. Kholil, sang 'Guru Para Ulama'.

Pada tahun 1926, Bakri menunaikan ibadah haji. Sepulang dari Makkah, namanya diganti menjadi Ihsan. Sejak saat itu ia sering dipanggil KH. Ihsan atau Syekh Ihsan. Pada tahun 1928, Syekh Ihsan berduka karena ayahnya, KH. Dahlan, dipanggil oleh Allah SWT. Pada waktu itu Syekh Ihsan masih di Makkah sehingga kepemimpinan Pondok Pesantren Jampes dipegang sementara oleh adik KH. Dahlan, yakni KH. Kholil. Dia mengasuh Pesantren Jampes hanya selama empat tahun. Syekh Ihsan mendengar berita itu segera pulang ke Indonesia.

Tidak lama setelah ayahnya meninggal, KH. Ihsan menikah. Ia menikah dengan seorang gadis dari desa Sumberrejo, Poncokusumo, Malang. Perkawinan ini tidak berlangsung lama karena mereka memutuskan untuk bercerai. Pasca perceraian itu, KH. Ihsan menikah lagi dengan putri KH. Muhyin, seorang kyai dari desa Durenan, Kediri. Namun, perkawinan kedua ini tidak berlangsung lama dan mereka pun berpisah. Kemudian KH. Ihsan menikah lagi untuk ketiga kalinya dengan seorang gadis dari desa Kapu, Pagu, Kediri. Perkawinan ketiga ini pun juga berakhir dengan perceraian. Kemudian KH. Ihsan menikah lagi untuk keempat kalinya dengan seorang gadis dari desa Polaman, Kediri. Perkawinan keempat ini pun berakhir dengan perceraian. Akhirnya, pada tahun 1932 $\mathrm{KH}$. Ihsan menikah lagi dengan seorang gadis dari desa Kayen kecamatan Pagu, Kediri bernama Surati atau Hj. Zaenab binti Haji Abdurrahman. Perempuan yang dinikahi KH. Ihsan terakhir ini adalah alumnus pesantren Jampes dan murid dari KH. Dahlan. Pernikahan KH. Ihsan dengan Surati (Hj. Zaenab) ini bertahan sampai KH. Ihsan meninggal. 
Pada tahun 1932, KH. Ihsan resmi menerima estafet kepemimpinan di Pondok Pesantren Jampes dari pamannya (KH. Kholil). Sejak saat itulah ia mengkonsentrasikan diri untuk mengelola pesantren peninggalan ayahnya itu. Ada banyak perkembangan di Pesantren Jampes setelah diasuh oleh Syekh Ihsan. Perkembangan yang cukup menonjol ketika pada tahun 1942 didirikan Madrasah Mafatihul Huda. Perkembangan pesantren secara kuantitas dan kualitas semakin jelas terlihat. Perkembangan secara kuantitas yakni jumlah santri terus bertambah dengan pesat dari tahun ke tahun (Al-Farizi, 2011). Secara kualitas, materi pelajaran juga semakin tertata dan terjadwal dengan baik. Agar pondok mampu menampung jumlah santri yang semakin banyak, pengelola Pondok Pesantren Jampes memutuskan untuk memperluas tanah pondok menjadi sekitar 1,5 hektar.

Sebagai pengasuh, Syekh Ihsan mengerahkan seluruh perhatian, pikiran, dan segenap tenaganya untuk 'diabdikan' kepada santri dan pesantren. Hari-harinya dipenuhi aktivitas mengajar santri (mengaji), shalat berjama'ah, shalat malam, muthola'ah kitab, ataupun menulis kitab. Meskipun banyak waktunya didedikasikan untuk santri, ternyata Syekh Ihsan tidak melupakan masyarakat di sekitarnya. Syekh Ihsan dikenal memiliki ilmu hikmah dan menguasai ketabiban. Hampir setiap hari, di sela-sela kesibukannya mengajar santri, Syekh Ihsan masih sempat menerima tamu dari berbagai daerah yang meminta bantuannya.

Pada waktu luang dia juga menyempatkan diri untuk menulis kitab. Dua kitab yang ditulisnya berjudul Siraj al-Thalibin Syarh Minhaj al-'Abidin karya Imam Ghozali, dan Manahij al-Imdad Syarah Irsyad al-'Tbad karya Syekh Zainuddin Al-Malibari. Kedua kitab ini sangat dikenal di kalangan intelektual muslim di Timur Tengah, terutama di Kairo. Kitab Manahijul Imdad ditulis pada tahun 1940 dan baru diterbitkan tahun 2005.

Selain dua kitab tersebut, masih ada dua kitab lagi karangan beliau, yaitu kitab Tashrih al-Ibarat dan kitab Irsyad al-Ikhwan. Kitab Tashrih al'Ibarat merupakan Syarh (penjelasan) dari kitab Natijat al-Miqat karya KH. Dahlan Semarang. Kitab ini ditulis pada tahun 1930, sedangkan kitab Irsyad al-Ikhwan merupakan Syarh dari kitab Tadzkirat al-Ikhwan karya KH. Dahlan Semarang. Kitab ini merupakan sebuah risalah yang khusus membahas hukum meminum kopi dan merokok dalam pandangan Islam. 
Kitab Irsyad al-Ikhwan ini akan dikaji lebih lanjut dalam bab III dan IV penelitian ini.

Selama hidupnya, KH. Ihsan tidak aktif dalam organisasi keagamaan apapun termasuk Nahdlatul Ulama. Dia juga tidak pernah menjadi anggota partai politik apalagi terjun di dunia politik praktis. Namun, pada masa revolusi fisik 1945, Syekh Ihsan memiliki andil cukup penting dalam perjuangan bangsa. Pondok Pesantren Jampes sering dijadikan tempat persinggahan sementara (transit) para pejuang dan gerilyawan Indonesia yang hendak menyerang Belanda.

Syekh Ihsan adalah ulama yang alim dan cerdas. Menurut penuturan ahli waris, dia pernah diminta oleh raja Faruq dari Mesir melalui utusannya untuk menjadi warga kehormatan Mesir sebagai Syekh pengajar di universitas Al-Azhar, Kairo. Permintaan itu berkenaan dengan kitab karangan beliau Siraj al-Thalibin Syarh Minhaj al-Abidin karya Imam Ghozali, yang sangat terkenal di Mesir. Kitab itu menjadi diktat resmi di Fakultas Ushuluddin Universitas Al-Azhar, Kairo dan menjadi rujukan wajib di beberapa universitas di Mesir dan Eropa. Namun permintaan raja Faruq itu ditolak oleh beliau dan memilih hidup dan mengajar di pondok pesantrennya sendiri di Jampes Kediri.

Pada hari Senin Tanggal 25 Dzulhijjah $1371 \mathrm{H}$. atau September 1952, Syekh Ihsan dipanggil oleh Allah SWT, pada usia 51 tahun. Dia meninggalkan ribuan santri, seorang istri dan delapan putra-puteri. Beberapa murid Syekh Ihsan yang mewarisi dan meneruskan perjuangannya dalam berdakwah melalui pesantren adalah: (1) Kiai Soim pengasuh pesantren di Tangir Tuban; (2) KH. Zubaidi di Mantenan Blitar; (3) KH. Mustholih di Kesugihan Cilacap; (4) KH. Busyairi di Sampang Madura; (5) K. Hambili di Plumbon Cirebon; dan (6) K. Khazin di Tegal.

Sumbangan Syekh Ihsan yang sangat besar adalah karya-karya yang ditinggalkannya bagi masyarakat muslim Indonesia, bahkan umat Islam seluruh dunia. Sudah banyak pakar yang mengakui dan mengagumi kedalaman karya-karya Syekh Ihsan, khususnya masterpiece Siraj athThalibin. Hal yang sangat membanggakan terutama ketika kitab tersebut diterbitkan oleh sebuah penerbit besar di Mesir, Musthafa al-Bab alHalab. Sayangnya, di antara kitab-kitab karangan Syekh Ihsan, baru Siraj ath-Thalibin yang mudah didapat. Itu pun baru dapat dikonsumsi 
oleh masyarakat pesantren sebab belum diterjemahkan ke dalam bahasa Indonesia.

Berikut daftar karya Syekh Ihsan Jampes, 1) Tashrih al-Ibarat (syarah dari kitab Natijat al-Miqat karya KH. Dahlan Semarang), terbit pada 1930 setebal 48 halaman. Buku ini mengulas ilmu falak (astronomi), 2) Siraj ath-Thalibin (syarah dari kitab Minhaj al-Abidin karya Imam alGhazali), terbit pada 1932 setebal \pm 800 halaman. Buku ini mengulas tasawuf, 3) Manahij al-Imdad (syarah dari kitab Irsyad al-'Ibad karya Syekh Zainudin al-Malibari), terbit pada 1940 setebal \pm 1088 halaman, mengulas tasawuf, dan 4) Irsyad al-Ikhwan li Bayani Syurb al-Qahwah wa ad-Dukhan (adaptasi puitik [plus syarah] dari kitab Tadzkirah al-Ikhwan fi Bayani al-Qahwah wa ad-Dukhan karya KH. Dahlan Semarang), t.t., tebal \pm 50 halaman. Buku ini berbicara tentang polemik hukum merokok dan minum kopi. Buku ini akan dikaji lebih lanjut pada penelitian ini.

\section{Kitab Irsyäd al-Ikhwän Karya Syekh Ihsan}

Buku berjudul Irsyād al-Ikhwān li bayāni syurb al-Qahwah wa alDukhān ini pada intinya menjelaskan duduk persoalan perihal kopi dan rokok dan polemik mengkonsumsinya. Buku ini lebih banyak membahas tentang polemik merokok daripada polemik meminum kopi. Meminum kopi dan merokok, menurut sebagian santri, sudah menjadi tradisi yang mendarah daging. Mayoritas kyai di pesantren adalah peminum kopi dan perokok, sehingga wajar apabila santrinya pun mayoritas adalah peminum kopi dan perokok.

Syekh Ihsan Jampes adalah sosok kyai pesantren yang termasuk peminum kopi dan perokok. Dia menjadi peminum kopi dan perokok karena tidak ada dalil dalam al-Qur'an dan Hadis Nabi yang melarang orang meminum kopi dan merokok. Posisi hukum meminum kopi dan merokok hanya ditemukan dari pendapat-pendapat/ijtihad para ulama saja, itupun bersifat $i k h t i l a f$ (terdapat perbedaan pendapat).

Posisi hukum mengopi dan merokok tidaklah tunggal, ada yang berpendapat haram, halal, mubah, dan makruh. Itu terjadi karena ada prakondisi dalam kasus merokok dan mengopi yang harus dipenuhi. Jika prakondisinya membuat mengopi dan merokok haram, maka hukumnya 
haram. Sebaliknya jika prakondisinya membuat mengopi dan merokok halal, maka hukumnya halal.

Kelebihan karya Syekh Ihsan Jampes ini di antaranya karena ia berhasil menempatkan pembahasan tentang kopi dan rokok secara berimbang, posisi hukumnya bergantung pada prakondisi yang melatarbelakanginya. Itu karena posisi hukum mengopi dan merokok terjadi ikhtilaf di kalangan ulama. Jumhur (mayoritas) ulama berpendapat hukum mengopi dan merokok makruh. Menjadi haram dikonsumsi jika tubuh seseorang akan mendapat mudharat atau kesadarannya menjadi hilang karena mengkonsumsinya.

Alasan inilah yang dijadikan pegangan kyai dan santri yang mengkonsumsi kopi dan rokok. Keharaman mengkonsumsinya diarahkan hanya bagi orang yang apabila jasadnya terkena kemudharatan, misalnya kesadarannya menjadi hilang. Sementara, bagi mereka (kyai maupun santri) mengopi dan merokok dirasa memberi manfaat, misalnya, untuk menyegarkan pikiran, melegakan pernapasan dan meminimalisir tekanan psikis akibat terlalu banyak menelaah kitab-kitab kuning.

\section{Pemikiran Syekh Ihsan Tentang Rokok}

Syekh Ihsan mengutip pendapat beberapa ulama, mengenai hukum rokok dan merokok. Ada ulama yang berpendapat haram, halal, mubah, makruh bahkan bermanfaat. Hal itu tergantung illatu al-ahkam (alasan penjatuhan status hukum) atau prakondisi yang menyertainya. Jika prakondisinya membuat merokok haram, maka hukumnya haram. Sebaliknya jika pra kondisinya membuat merokok halal, maka hukumnya halal. Namun demikian, ia setuju dengan pendapat jumhur ulama yang mengatakan bahwa hukum merokok adalah makruh.

Berdasarkan hal itulah, nampaknya, dapat dipahami mengapa dalam lingkungan pesantren, baik kyai maupun santri merokok. Menurut mereka keharaman merokok diarahkan hanya bagi orang yang apabila merokok maka jasadnya terkena kemudharatan yaitu kesadaran menjadi hilang. Sementara bagi mereka yang apabila merokok dirasa memberi manfaat, misalnya, untuk menyegarkan pikiran, melegakan pernapasan dan meminimalisir tekanan psikis akibat terlalu banyak menelaah kitab-kitab kuning, maka merokok hukumnya mubah (boleh). Pada kondisi demikian 
merokok menjadi boleh atau halal. Adapun ulama yang mengharamkan rokok berpendapat bahwa rokok merusak kesehatan, menyebabkan orang mabuk, tidak berkesadaran, baunya tidak disenangi orang lain, dan dipandang sebagai pemborosan (isyrof). Dengan kata lain, rokok membawa madharat yang bisa menghalangi ibadah.

Rokok juga bisa menjadi haram jika dapat melalaikan seseorang dari, misalnya, memberi nafkah terhadap orang-orang yang wajib dinafkahi, atau dapat melalaikan seseorang dari melakukan ibadah fardu lainnya. Hukum haram juga bisa ada jika perokok membeli rokok dengan harta yang dibutuhkan untuk nafkah keluarga. Sedangkan yang memperbolehkan mengatakan bahwa rokok tidak najis, atau menghilangkan kesadaran. Bahkan, rokok memberikan semangat baru dalam menjalani kehidupan. Bagi kelompok ini, salah apabila ada orang yang mengatakan rokok haram, baik zatnya, maupun mengkonsumsinya. Menurut mereka merokok adalah mubah (boleh). Pendapat masyhur para ulama mengatakan bahwa merokok adalah makruh. Ada juga yang mengatakan merokok boleh saja tetapi hukum makruh tetap menyertainya.

Terlepas dari mana yang benar dari pendapat-pendapat itu, Syeikh Ihsan dalam buku ini telah menyajikan tulisan secara cukup proporsional/ berimbang. Dia memberikan kebebasan kepada pembaca untuk memilih. Dia telah berusaha memposisikan rokok secara netral, posisi hukumnya tergantung pada kondisi yang menyertainya. Itu karena posisi hukum merokok terjadi ikhtilaf di kalangan ulama. Jumhur ulama berpendapat hukum merokok makruh. Menjadi haram dikonsumsi jika tubuh seseorang akan mendapat madharat atau kesadarannya menjadi hilang karena mengkonsumsinya. Namun demikian, pada beberapa bagian tertentu Syekh Ihsan telah memberikan komentar atau pendapat yang terkesan cenderung mendukung pihak yang membolehkan merokok. Hal ini dapat dipahami karena dia adalah perokok sekaligus peminum kopi.

\section{Pendapat Ulama dan Pemikiran Syekh Ihsan tentang Keharaman Rokok}

Ulama yang mengharamkan rokok di antaranya Syekh asy-Syihab al-Qalyubi, Syekh Ibrahim al-Laqqani al-Maliki, Al-Muhaqqiq al-Bujairimi, Syekh Hasan asy-Syaranbila, Syekh Abdullah ibn Ahmad Basudan, Syekh Ibnu Hajar, Syekh Abdullah ibn Alwi al-Haddad, dan Syekh Muhammad 
Fiqhi al-Aini. Syekh Ihsan berpendapat bahwa pendapat mereka umumnya lemah, namun Syekh Ihsan tidak memberikan alasan memadai atas pendapatnya itu.

Syekh asy-Syihab al-Qalyubi berpendapat rokok dan candu serta benda-benda lain sejenis yang membahayakan pikiran tidak dihukumi najis, namun haram menggunakannya. Rokok dapat menjadikan tubuh lesu, sesak nafas, dan gejala lain yang sejenis. Bahkan, menurut sumber yang dikutip olehnya menyebutkan bahwa sesungguhnya merokok dapat menimbulkan perasaan kepala berputar-putar alias puyeng.

Syekh Ibrahim al-Laqqani al-Maliki berpendapat bahwa di antara tumbuhan yang membahayakan akal/pikiran itu adalah tembakau (rokok) dan candu yang sekarang sudah cukup dikenal masyarakat. Tumbuhan lain yang termasuk candu yaitu ganja, buah pala, minyak ambar, dan zakfaran (dalam jumlah banyak), serta tumbuhan lain yang dapat membahayakan dan merusak pikiran.

Al-Muhaqqiq al-Bujairimi menyatakan bahwa merokok hukumnya haram. Mengkonsumsi sesuatu yang dapat membahayakan badan atau pikiran hukumnya adalah haram. Kaidah ini berkonsekuensi pada diharamkannya rokok. Syekh Hasan asy-Syaranbila adalah ulama dari mazhab Hanafi. Dia juga melarang mengkonsumsi rokok dan memperdagangkannya.

Syekh Abdullah ibn Ahmad Basudan berpendapat bahwa, "Semua yang terkandung dalam hasyisy dapat dibilang merupakan keburukan, dan segala penyakit akan menjangkit pada mereka yang menikmati tembakau, seandainya kalian memahaminya”. Pendapat serupa juga dikemukakan oleh Syekh Ibnu Hajar yang menyatakan bahwa tembakau termasuk barang yang kotor dan mengandung penyakit.

Syekh Abdullah berpendapat bahwa menghisap rokok (dengan mulut) hukumnya haram. Demikian pula menghirup (dengan hidung) juga haram. Menghirup rokok dengan hidung, menurutnya, lebih jelek daripada menghisapnya melalui mulut. Syekh Abdullah ibn Alwi alHaddad adalah guru Syekh Ihsan, dan KH. Dahlan. Syekh Muhammad Fiqhi al-Aini berpendapat sama dengan Syekh Abdullah bahwa rokok dapat membahayakan, sehingga hukumnya haram. 
Menurut Syekh Ihsan pendapat ini lemah dan tidak dapat diterima, namun di dalam kitab Irsyād al-Ikhwān Syekh Ihsan tidak memberikan penjelasan mengapa demikian. Syekh Ihsan hanya menyatakan pendapat tersebut juga ditentang oleh ulama sejaman bernama Ali bin Muhammad al-Ajhuri al-Maliki. Ali menyusun dua risalah yang memuat hal-hal yang boleh dinikmati dan tidak berbahaya, salah satunya adalah rokok.

\section{Pendapat Ulama dan Pemikiran Syekh Ihsan tentang Keharaman Rokok}

Ulama yang berpendapat bahwa rokok halal dikonsumsi di antaranya Al-Imam Abd al-Ghani an-Nabilisi, Al-Babily, Al-Barmawi, AlFadhil Mas'ud ibn Hasan al-Qanawi asy-Syafi'i, Syekh as-Sulthan al-Halab, Al-Alamah asy-Syabramalis, Syekh 'Ali al-Ajhuriy, Ar-Rusyd, Syekh Ahmad al-Maliki, Syekh Mar'a al-Muqaddas al-Hanbali, Al-Allamah Mas'ud ibn Husain al-Fatawi asy-Syafi'i, Syekh Abdurrauf al-Manawi asy-Syafi'i, dan Syekh Ismail as-Sindiyah. Pendapat mereka menurut Syekh Ihsan layak dijadikan pegangan bagi masyarakat, termasuk dirinya.

Al-Imam Abd al-Ghani an-Nabilisi menyatakan bahwa rokok tidak haram. Al-Babily berpendapat bahwa menghisap rokok hukumnya halal. Keharaman rokok bukan karena rokok itu sendiri haram (haram li dzatih), melainkan karena ada unsur dan faktor luar yang mempengaruhi ataupun merubah hukum halal ini. Pendapat ini didukung oleh AlBarmawi. Al-Barmawi berpendapat bahwa menghisap rokok hukumnya halal, keharamannya karena ada unsur dari luar yang mempengaruhinya. Berdasarkan pendapat itu, hukum merokok menjadi relatif, bergantung pada ada tidaknya madharat atau bahaya pada si perokok itu.

Al-Fadhil Mas'ud ibn Hasan al-Qanawi asy-Syafi'i mengatakan bahwa rokok halal dikonsumsi, bahkan rokok dapat digunakan untuk mengobati penyakit, misalnya serak/parau. Pendapat serupa dikemukakan oleh Syekh as-Sulthan al-Halab. Ia berpendapat menghisap rokok tidaklah haram, bahkan makruh pun tidak. Pendapat ini didukung oleh Al-Alamah Asy-Syabramalis yang berpendapat bahwa menghisap rokok tidak haram, bahkan tidak makruh. Demikian pula Syekh 'Ali al-Ajhuriy berpendapat bahwa rokok halal dikonsumsi. Dia berfatwa, "Rokok halal hukumnya kecuali bagi orang-orang tertentu yang mungkin dapat hilang kesadarannya 
karena rokok dan bagi orang yang badannya akan mendapat madharat (bahaya) jika merokok".

Ulama ar-Rusyd berpendapat bahwa "Tidak adanya dalil yang dapat dijadikan dasar untuk mengharamkan rokok. Menghisap dan mengkonsumsi rokok hukumnya mubah". Syekh Ahmad al-Maliki sependapat dengan berpendapat Rusyd bahwa selama tidak ada hal yang memicu terjadinya dua hal (kehilangan akal dan badan tertimpa sakit karena rokok), maka merokok hukumnya tidak haram.

Syekh Mar'a al-Muqaddas al-Hanbali juga berpendapat "Menghisap rokok tidaklah haram sekiranya perbuatan itu tidak berkonsekuensi pada kerusakan tertentu. Menghisapnya sama saja dengan menghisap asap api biasa yang kebetulan tidak dimatikan oleh seseorang, yang mana tidak ada satu pendapat pun yang mengharamkannya. Al'Allamah Mas'ud ibn Husain al-Fatawi asy-Syafi'i berpendapat sama dengan pendapat Syekh Mar'a al-Muqaddas al-Hanbali.

Syekh Abdurrauf al-Manawi asy-Syafi'i mengatakan bahwa menghisap rokok hanya diharamkan bagi orang yang --ketika merokok-hilang kesadarannya, tidak yang lain. Syekh Ismail as-Sindiyah mendukung pendapat yang mengatakan merokok tidaklah haram li dzatih, tidak haram karena hukum asalnya haram. Sebaliknya, hukumnya mubah.

Berdasarkan pendapat-pendapat itu, Syekh Ihsan menyatakan bahwa jumhur (mayoritas) ulama sepakat bahwa haramnya rokok hanya dikhususkan bagi orang yang tubuhnya akan mendapat madharat jika merokok, atau mereka yang kesadarannya hilang karena merokok. Penakwilan ini sudah sangat populer di kalangan ulama mazhab Hanafi, Hanbali, dan Syafi'i. Pendapat ini menurut Syekh Ihsan layak menjadi pegangan umat.

\section{Pendapat Ulama dan Pemikiran Syekh Ihsan tentang Kemakruhan Rokok}

Ulama yang berpendapat bahwa rokok hukumnya makruh di antaranya Imam al-Bajuri, Syekh Abd al-Hamid, Imam asy-Syarqawi, Imam al-Kurdi, Al-Jamal ar-Ramli, Muhammad Sa'id Babashil, dan Syekh Muhammad ibn Musa an-Nasawi. 
Imam al-Bajuri di dalam Hasyiyah 'Ala Syarh al-Ghayah bagian Kitab al-Buyu' berpendapat bahwa rokok hukumnya makruh. Dia menyatakan bahwa pendapat yang menyatakan rokok itu haram merupakan pendapat yang lemah. Demikian pula pendapat yang mengatakan bahwa rokok itu mubah juga lemah. Pendapat ini dianggap mu'tamad (layak menjadi pegangan). Syekh Abd al-Hamid juga berpendapat sama bahwa rokok itu makruh. Dia mengkritik pendapat Imam ar-Rasyid yang mengatakan bahwa rokok itu halal dan mengatakan, "Perselisihan tentang haramnya rokok itu sendiri sudah cukup menunjukkan tidak tepatnya hukum mubah”.

Imam asy-Syarqawi mengkritik pernyataan al-Qalyubi yang mengharamkan rokok dengan alasan bahwa rokok menyebabkan sesak napas dan kelesuan badan. Ia mengatakan bahwa pernyataan itu layak ditinjau ulang, sebab hukum rokok adalah makruh. Dia membenarkan bahwa merokok haram bagi orang yang jika merokok dapat dipastikan akan terkena madharat, tetapi keharaman itu hanya berlaku khusus bagi orang itu. Bahkan, madu pun juga bisa haram bagi orang yang dilarang meminumnya.

Imam al-Kurdi dalam kitabnya al-Fatawa menyatakan bahwa merokok hukumnya haram apabila menimbulkan bahaya bagi orang itu, baik mengenai badan maupun pikirannya. Terkait dengan pendapat ini, Syekh Ihsan mengatakan dalam kasus lain sebagian ulama mengatakan memakan lumpur hukumnya haram, tetapi apabila ada sesuatu yang menyebabkan boleh, hukumnya pun berubah menjadi mubah, bahkan bisa menjadi sunnah, misalnya untuk obat.

Al-Jamal ar-Ramli berpendapat bahwa secara umum hukum rokok adalah makruh. Keharaman rokok bagi orang-orang tertentu tidak memiliki kekuatan hukum yang pasti (ghair al-jazim) sebagaimana hukum memakan bawang mentah. Muhammad Sa'id Babashil berpendapat bahwa merokok hukumnya makruh. Ia mendukung pendapat al-Bajuri berdasarkan kitabkitab yang dibacanya.

Syekh Muhammad ibn Musa an-Nasawi berpendapat merokok boleh saja, namun diikuti dengan kemakruhannya. Artinya, jika si perokok tidak mengalami ketergantungan terhadap rokok yang dihisapnya atau dia dapat meninggalkan atau berhenti merokok, maka berlaku hukum itu (mubah diikuti makruh), namun jika si perokok mengalami ketergantungan 
atau tidak bisa meninggalkan rokok maka hukum mubah itu tidak disertai kemakruhannya.

Terkait dengan pendapat ini, Syekh Ihsan mengatakan dalam kasus lain sebagian ulama mengatakan memakan lumpur hukumnya haram, tetapi apabila ada sesuatu yang menyebabkan boleh, hukumnya pun berubah menjadi mubah, bahkan bisa menjadi sunnah, misalnya untuk obat. Pendapat bahwa rokok itu hukumnya makruh didukung oleh Syekh Ihsan dan ia menganggap fatwa ini merupakan fatwa yang paling sahih. Oleh karena itu, Syekh Ihsan menganjurkan untuk diamalkan.

\section{Simpulan}

Berdasarkan uraian di atas dapat disimpulkan sebagai berikut: Pertama, kitab Irsyad al-Ikhwan pada intinya menjelaskan kedudukan hukum mengkonsumsi rokok. Kitab ini ditulis oleh Syekh Ihsan Muhammad Dahlan dari Pondok Pesantren Jampes, Kediri, Jawa Timur. Syekh Ihsan Jampes adalah sosok kyai pesantren yang termasuk perokok berat. Dia menjadi perokok berat karena tidak ada dalil dalam al-Qur'an dan Hadis Nabi yang melarang orang merokok. Menurut Syekh Ihsan, posisi hukum merokok hanya ditemukan dari pendapat-pendapat/ijtihad para ulama saja, itupun bersifat ikhtilaf (terdapat perbedaan pendapat). Kitab ini terdiri atas empat bagian, yakni mukaddimah, ulama yang mengharamkan rokok, ulama yang menghalalkan rokok, dan permasalahan fikih ihwal rokok.

Kedua, pemikiran Syekh Ihsan tentang hukum merokok dalam kitab Irsyad al-Ikhwan secara umum dapat disimpulkan sebagai berikut. Posisi hukum merokok tidaklah tunggal, ada yang berpendapat haram, halal, mubah, makruh bahkan bermanfaat. Itu terjadi karena ada prakondisi dalam kasus merokok. Jika prakondisinya membuat merokok haram, maka hukumnya haram. Sebaliknya jika prakondisinya membuat merokok halal, maka hukumnya halal.

Ketiga, ulama yang menyatakan rokok haram menganggap bahwa: (1) rokok dapat membahayakan kesehatan. (2) rokok dapat memabukkan dan melemahkan tubuh. (3) bau rokok/perokok tidak disenangi sehingga dapat menyakitkan hati seseorang. (4) merokok dianggap suatu pemborosan dan cermin sifat berlebihan. Pendapat ini menurut Syekh 
Ihsan dianggap lemah dan tidak dapat diterima. Sebaliknya ulama yang menghalalkannya beralasan, antara lain: (1) membangkitkan kinerja syaraf. (2)mengurangi lemak tubuh. (3) membunuh beberapa jenis mikroba. (4) untuk menghilangkan serak. (5) membangkitkan seseorang dari kelesuan. Pendapat ini menurut Syekh Ihsan layak dijadikan pegangan oleh masyarakat.

Keempat, bantahan-bantahan ulama pendukung rokok terhadap ulama-ulama yang mengharamkannya: (1) Merokok tidak sama sekali menghilangkan kesadaran. (2) Jika rokok haram karena membawa mudharat, maka keharamannya disebabkan oleh madharatnya, suatu unsur luar yang datang. (3) Rokok menjadi haram jika dapat melalaikan seseorang dari, misalnya, memberi nafkah terhadap orang-orang yang wajib dinafkahi. Atau dapat melalaikan seseorang dari melakukan ibadah fardu lainnya. Hukum haram juga bisa ada jika perokok membeli dengan harta yang dibutuhkan untuk nafkah keluarga. Rokok haram bagi seseorang yang berbahaya apabila mengkonsumsinya, baik badan maupun bukan. Mereka menganalogkan dengan pendapat Al-Ghazali bahwa madu pun bisa haram jika dikonsumsi oleh orang yang darahnya panas. Pendapat ini didukung oleh Syekh Ihsan dalam kitab Irsyād Al-Ikhwān. 


\section{BIBLIOGRAFI}

Aliman, Ibnu Abdullah, Jadi Benci Merokok Dengan Terapi Asmaul Husna, Bimbingan Untuk Para Perokok yang Ingin Berhenti Merokok. Jogyakarta: Penerbit Perkutut, 2011.

Bruinessen, Martin Van, Kitab Kuning, Pesantren dan Tarekat, cet. ke-1. Bandung: Mizan, . 1995.

Dhofier, Zamakhsyari, Tradisi Pesantren, Studi Tentang Pandangan Hidup Kyai. Jakarta: LP3ES, 1982.

Fauzi, Nasim, H.M.dr., Siapa Bilang Merokok Harom? Minyak Kedelai dan Minyak Kacang Sebagai Penyebab Penyakit Jantung; Rokok yang Dijadikan Kambing Hitam!.Malang: Surya Pena Gemilang Publishing, 2010.

Ihsan, Syekh Muhammad Dahlan, Terjemah Siraj ath-Thalibiin. Jilid 1. Kediri: Jampes, 1431 H/2010 M.

Ihsan, Syekh Muhammad Dahlan, Siraj ath-Thalibiin Syarah Minhaj al'Abidiin. Juz I. Dar al-Fikr

Ihsan, Syekh Muhammad Dahlan, Siraj ath-Thalibiin Syarah Minhaj al'Abidiin. Juz II. Dar al-Fikr

Jampes, Syaikh Ihsan, Kitab Kopi dan Rokok. Yogyakarta: Penerbit Pustaka Pesantren, 2009.

Jaya, Muhammad, Pembunuh Berbahaya Itu Bernama Rokok. Sleman Yogyakarta: Penerbit Riz’ma, 2009.

Mughni. Busrol Karim A. KH, Syekh Ihsan Muhammad Dahlan Al-Jampesi Al-Kediri (Pengarang Siraj al-Thalibiin). Cetakan ke-6. Kediri: Jampes-Kediri, 2006.

Rif'an, Ahmad Rifa'I Merokok Haram. Jakarta: Penerbit Republika, 2010.

Shihab, Quraish, M. , M. Quraish Shihab Menjawab 1001 Soal Keislaman yang Patut Anda Ketahui. Cet. X, Rabi'ul Awal 1432 H. Ciputat Tangerang: Lentera Hati, 2011. 